JINOTEP Vol 8 (2) (2021): 157-166

DOI: $10.17977 / \mathrm{um} 031 \mathrm{v} 8 \mathrm{i} 22021 \mathrm{p} 157$

JINOTEP (Jurnal Inovasi Teknologi Pembelajaran)

Kajian dan Riset Dalam Teknologi Pembelajaran

http://journal2.um.ac.id/index.php/jinotep/index

\title{
ANALYSIS OF THE FORMATIVE ASSESSMENT PLANNING DURING ONLINE LEARNING: A CASE STUDY
}

\author{
Kadek Agus Toni Mahendra, Ni Luh Putu Eka Sulistia Dewi, Luh Gede Eka Wahyuni \\ Pendidikan Bahasa Inggris-Universitas Pendidikan Ganesha,-Kota Singaraja-Indonesia
}

\begin{tabular}{l} 
Article History \\
\hline Received: 08-06-2021 \\
Accepted: 01-07-2021 \\
Published: 04-07-2021 \\
Available onlone: 03- \\
07-2021
\end{tabular}

Keywords

formative assessment planning; online

learning; assessment for learning

\begin{abstract}
Abstrak
Penelitian ini bertujuan untuk menganalisis perencanaan penilaian formatif guru mata pelajaran bahasa Inggris dalam pembelajaran online di SMP Negeri 1 Singaraja. Penelitian ini menggunakan deskriptif kualitatif, lima Guru bahasa Inggris di SMP Negeri 1 Singaraja dipilih menjadi subjek dalam penelitian ini. Subjek dipilih dengan teknik purposive sampling. Metode pengumpulan data yang digunakan yaitu studi dokumen dan wawancara. Hasil penelitian menunjukkan bahwa semua guru bahasa Inggris sudah mengintegrasikan perencanaan penilaian formatif ke dalam rencana pembelajaran. Teknik penilaian formatif yang disiapkan oleh guru bahasa Inggris dalam pembelajaran online yaitu teknik bertanya, penugasan formatif, ulangan harian, diskusi, dan penilaian diri. Hasil penelitian ini juga menunjukan bahwa dimensi kriteria keberhasilan masih perlu diperhatikan dan ditingkatkan guna memaksimalkan manfaat penilaian formatif dalam pembelajaran online.

Abstract

This study aimed at analyzing the teachers' formative assessment planning for English subject in online learning at SMP Negeri 1 Singaraja. This study used qualitative descriptive research design. fives English teachers at SMP Negeri 1 Singaraja were used as subject in this study. The subjects were chosen by purposive sampling technique. The data collection methods employed were document study and interview to answer the research question qualitatively. The findings showed that all English teachers successfully integrated formative assessment planning into their lesson plan. There were formative techniques that appear in the lesson plan, such as questioning technique, formative task, daily test, online discussion, and self-assessment. This results of the study also showed that the dimensions of success criteria still need to be considered and improved in order to maximize the benefit of formative assessment in online learning.
\end{abstract}

Corresponding author: Kadek Agus Toni Mahendra

Adress: Dusun Taman Desa Munduk,

Instansi: Universitas Pendidikan Ganesha,

E-mail: kadekagustonimahendra19@undiksha.ac.id
2021 Universitas Negeri Malang p-ISSN 2406-8780 e-ISSN 2654-7953 
158 JINOTEP (Jurnal Inovasi dan Teknologi Pembelajaran) Kajian dan Riset dalam Teknologi Pembelajaran Vol.8, No.2, Juli 2021, Hal. 157-166

\section{INTRODUCTION}

Seeing the varied conditions and situations of students during online learning, a process-oriented assessment or what is also known as formative assessment is needed to modify teaching activities. Formative assessment is one of powerful assessment used to improve students' achievement (Wiliam, 2013). The implementation of formative assessment in online learning can enhance students' achievement scores (McLaughlin \& Yan, 2017). Therefore, this type of assessment plays significant role since it can help teachers to make instructional adjustments to improve student's success.

One of the important steps in conducting an assessment is planning. According to McCharty (2017) suggests formative assessment cycles such as (1) collect students' data, (2) analyze students data, (3) plan intervention and extension for learning and (4) implement the formative assessment. It can be seen that planning cannot be separated from the formative assessment cycle because it is the next step that teachers must do after the teacher analyze student's data. Kemendikbud Republik Indonesia (2020), the data from the results of formative assessments can be used to design further learning activities to support the achievement of higher quality learning and ensure the achievement of learning objectives for each student. It also explains that in order to make the formative assessment and learning to become a unit, formative assessment planning should be made integrated with the teachers' lesson plan.

There are several dimensions that must be included in the formative assessment planning. This study used three dimensions of formative assessment planning adapted from Andrade \& Heritage (2017) such as, learning goal, criteria for success, and learning progression.

The first is learning goal, in implementing formative assessment learning goal should be clearly identified to ensure that students understand what they are learning and why it is worth learning (Andrade \& Heritage (2017). This element has significant role because it will make students become aware of the expected performance of the material/unit. The second dimension is criteria for success, the purpose of the criteria is to help students demonstrate that they have met the learning goal (Wylie and Lyon, 2016). Last but not least is learning progression, it allows teachers to identify students' progress and misconceptions students have about the learning. In terms of instruction, it also helps the teacher to make connections between prior and successive learning. The information from formative assessment can be used to help teachers decide on appropriate instructional actions to enhance students' learning. Therefore, these dimensions are fundamental elements to be concerned that used as a reference in designing ideal formative assessments planning.

Considering the role of formative assessment planning before conducted formative assessment in learning, the teacher should be prepared in every subject, including English. English becomes the most commonly spoken language in the world (Nishanthi,2018). Thus, English is the first foreign language taught in Indonesia. As an international language, English learning is also learned by many students in the world.Thus, in order to achieve a good learning outcome in English learning, the teacher should implement good assessment in the learning process. Moreover, having good formative assessment planning is hoped can support formative assessment practice in online learning. In pre-observations, one of the schools that have been implementing formative assessment during traditional face-to-face learning and online learning is SMP N 1 Singaraja. It also found that the English teacher at SMP Negeri 1 Singaraja also conducted formative assessment in various media that is both asynchronous and synchronous during online learning. However, Perera-Diltz \& Moe (2012) states that assessment (formative or summative) of student learning in online learning cannot be merely transferred from a 
traditional face-to-face classroom, but the teacher should be re-conceptualized in accordance with the media used. Thus, it can be assumed that the teacher in SMP Negeri 1 Singaraja already made adjustments to the planning of formative assessment in online learning during the COVID-19 period, which differentiates the online version from face-toface learning.

Hence, this study arises to investigate the formative assessment planning during online learning. By describing and analyzing the formative assessment planning in online learning may provide inspiration and example for other teachers to adopt or adapt the planning.

\section{METHOD}

This research focused on the analysis of formative assessment planning in online learning. This research used descriptive qualitative method. According to Sugiyono (2018), descriptive research refers to the research conducted to determine the value of one or more independent variables without making comparisons and connecting with other variables. In addition, Atmowardoyo (2018) explains that descriptive research is defined as a research design that is applied to describe a phenomenon that already exists as accurate as possible. Regarding these characteristics, the descriptive method is considered appropriate as the design of this research.

Purposive sampling was used to determine the subjects. According to Creswell (2012), purposive sampling is defined as a sampling technique with certain judgments in which researchers intentionally choose individuals and subjects to investigate the phenomenon. The setting of this study took place at SMP Negeri 1 Singaraja. There were five English teachers as the subject of the study.

In this research, the data were collected using document study and interviews. The study used pre-determined dimensions of formative assessment planning adapted from Andrade \& Heritage (2017) to develop indicator instruments. There were 11 indicators from checklist and 10 questions in the semi-structured interview. The collected data were analysed descriptively using qualitative analysis suggested by Cresswell (2012) which included 1) Preparing and organizing the data, 2) Exploring and coding data, 3) Describing findings, 4) Representing and report the findings, 5) Interpreting the findings and 6) Validating the accuracy findings. Besides, the researchers also used trustworthiness to reassure the reads based on the results of this study by using data triangulation, investigator triangulation, triangulation methods, and theory triangulation (Heale \& Forbes, 2013) to confirm the findings.

\section{RESULTS}

This section analyses teachers' formative assessment planning on the teachers' lesson plan. 15 one page lesson plans were analyzed by using the ideal of formative assessment planning adapted from (Andrade \& Heritage, 2017). There were several indicators used in analyzing teachers' formative assessment planning dimensions which were grouped into three dimensions, namely: (1) Learning goal, (2) Success criteria, (3) Learning progressions. The 15 teachers' lesson plans were checked using checklist instrument to identify formative assessment planning in the teacher-made lesson plan. The details of the findings were presented briefly in Table 1 .

Table 1 showed that all English teachers had made a plan before implementing formative assessment in online learning. Based on the interview data, before the English teachers designing the lesson plan, they have made an agreement with students regarding online learning meetings. They divided class meetings into two methods of learning, namely synchronous and asynchronous learning. The synchronous meeting was used to explain the material and provide feedback on the students' work. All teachers argued that the importance of face-to-face meetings in online settings through zoom or google meet to monitor whether or not students were studying at home seriously. In comparison, the asynchronous meeting was used to provide material, tests, and tasks. 
160 JINOTEP (Jurnal Inovasi dan Teknologi Pembelajaran) Kajian dan Riset dalam Teknologi Pembelajaran Vol.8, No.2, Juli 2021, Hal. 157-166

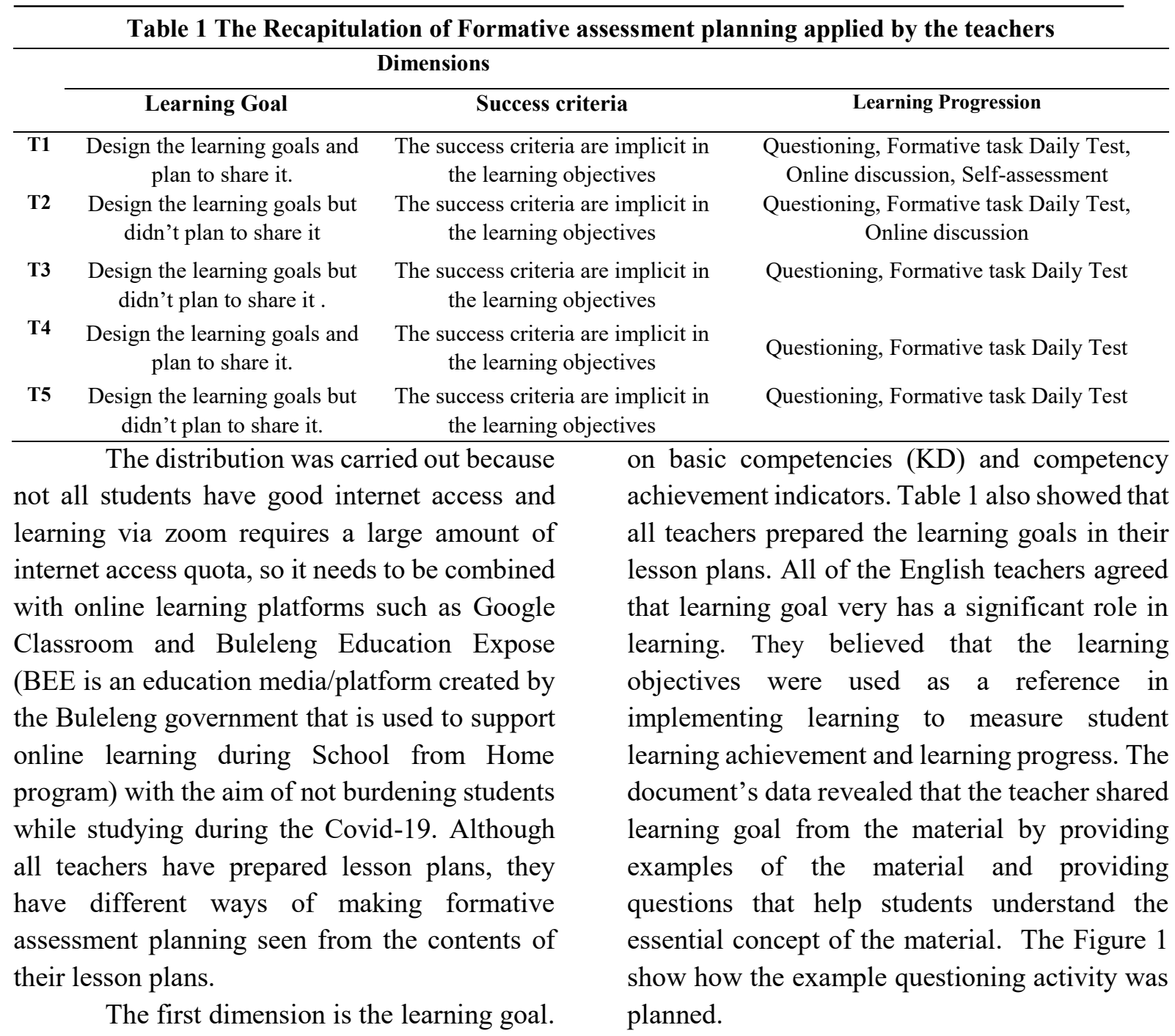

The teacher already made a learning goal based

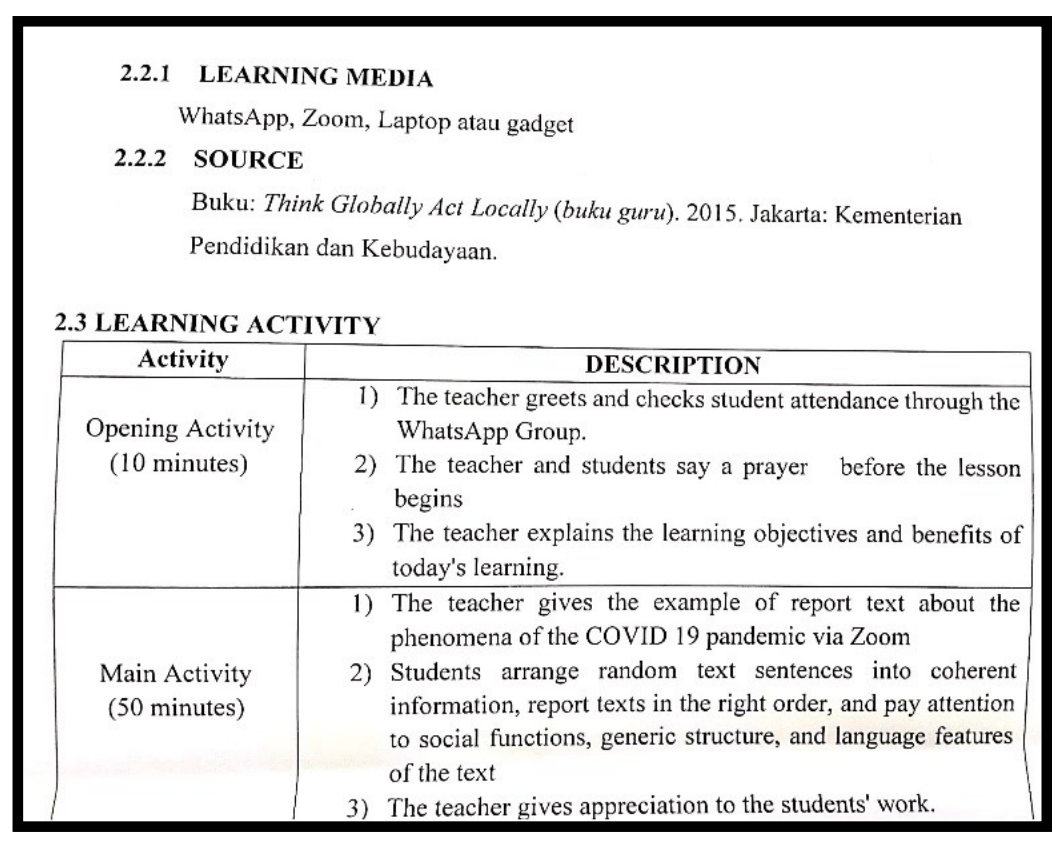

Figure 1 Providing an example as a way of sharing learning goal to students 


\begin{tabular}{|c|c|}
\hline Activity & Description \\
\hline $\begin{array}{l}\text { Opening Activity } \\
\text { (10 minutes) }\end{array}$ & $\begin{array}{l}\text { 1. The teacher greets and checks student attendance through the } \\
\text { WhatsApp Group. } \\
\text { 2. The teacher and students say a prayer before the lesson } \\
\text { begins } \\
\text { 3. The teacher explains the learning objectives and benefits of } \\
\text { today's learning. }\end{array}$ \\
\hline $\begin{array}{l}\text { Main Activity } \\
\text { (50 minutes) }\end{array}$ & $\begin{array}{l}\text { 1. The teacher sends the worksheet related to the report text via } \\
\text { WhatsApp Group } \\
\text { 2. The teacher explains the procedure for working on the } \\
\text { worksheet and its assessment aspects } \\
\text { 3. Students work on the worksheet from the report text provided } \\
\text { by the teacher } \\
\text { 4. Teachers and students discuss the results of student work via } \\
\text { zoom }\end{array}$ \\
\hline
\end{tabular}

Figure 2 Providing questions as a way of sharing Learning goal to students

Figure 1 showed that the teacher started the class by providing the authentic real-life example of report text about COVID-19 in Indonesia. The teacher believed that giving real examples that follow the current situation will make it easier for students to develop students' contextual understanding of the material. Besides giving examples, the teacher also planned to conduct questioning in order to provide students with an understanding of learning goal. The Figure 2 showed questioning activity was planned.

Figure 2. showed that the teacher has planned to carry out the questioning process related to the narrative text at the beginning of the class. The teacher believed that the process of questioning at the beginning of learning could encourage students to think more deeply about the material to be given. In addition, this study also found the teachers have provided time and opportunities for students to understand the learning goals and discuss the learning goals seen from the time allocation made in the lesson plans.

The second dimension is the criteria for success. The purpose of the criteria is to help students demonstrate that they have met the learning goal. It refers to the Indicator of Competency Achievement in Indonesians' Lesson Plan (RPP). In this study, the simplified one pages lesson plan was investigated. Based on the Circular of the Ministry of Education and Culture Number 14 of 2019 concerning Simplification of the Lesson Plan, it is stated that of the 13 (thirteen) lesson plan components that have been regulated in the Regulation of the Minister of Education and Culture Number 22 of 2016 concerning Basic and Secondary Education Process Standards, which simplifies to be the core components, such as the learning objectives, the steps (activities) of learning, and assessment which must be carried out by the teacher, while the other components are complementary. Therefore, in this study, the success criteria as one of the elements of formative assessment planning were implicit in the learning goal. It can be seen in Table 1 all teachers have compiled the success criteria that were implied in the learning objectives.

This study found that the teacher planned to explain the procedures of the task and the criteria for success in the main activity. T1 argued that assessment criteria in learning was essential because it make it easier for students - 
162 JINOTEP (Jurnal Inovasi dan Teknologi Pembelajaran) Kajian dan Riset dalam Teknologi Pembelajaran Vol.8, No.2, Juli 2021, Hal. 157-166

\begin{tabular}{|c|c|}
\hline Activity & Description \\
\hline $\begin{array}{l}\text { Opening Activity } \\
\text { (10 minutes) }\end{array}$ & $\begin{array}{l}\text { 1. The teacher greets and checks student attendance through the } \\
\text { WhatsApp Group. } \\
\text { 2. The teacher and students say a prayer before the lesson } \\
\text { begins } \\
\text { 3. The teacher explains the learning objectives and benefits of } \\
\text { today's learning. }\end{array}$ \\
\hline $\begin{array}{c}\text { Main Activity } \\
\text { (50 minutes) }\end{array}$ & $\begin{array}{l}\text { 1. The teacher sends the worksheet related to the report text via } \\
\text { WhatsApp Group } \\
\text { 2. The teacher explains the procedure for working on the } \\
\text { worksheet and its assessment aspects } \\
\text { 3. Students work on the worksheet from the report text provided } \\
\text { by the teacher } \\
\text { 4. Teachers and students discuss the results of student work via } \\
\text { zoom }\end{array}$ \\
\hline
\end{tabular}

Figure 3 Planning the delivery of the assessment criteria by the teacher

to provide an overview of the assessed aspects.

For example, data from the document showed that $\mathrm{T} 1$ designed the aspects of the assessment related to students' writing based on criteria such as; grammar, content, and punctuation. Figure 3. shows how the teacher shares the success criteria was planned.

In comparison, this study found that some teachers did not plan to share the success criteria to students seen from the lesson plan they have made. T3 was one of the teachers who did not plan to share the success criteria with students seen from their lesson plan. T3 argued that he explained the assessment criteria only at the beginning of the meeting in each unit of material.

Surprisingly, other teachers who did not share the success criteria reasoned that they purposefully did not share the assessment criteria with students not to burden students in online learning. T2 argued that establishing 'rigid' assessment criteria might decrease students' creativity in expressing their ideas. T2 emphasized in the interview the most important thing in teaching during online settings was making students feel comfortable in the online class. This finding was rather not appropriate because as found by several studies (William, 2013; Wylie and Lyon,2016), assessment criteria can show students how to achieve the learning goals. Therefore, some of the teachers' planning needed to be detailed in order to achieve the potentials benefit of formative assessment.

The last dimension of formative assessment planning is learning progression. This dimension focus on how the teachers monitor the position of their students' learning/progress. The study revealed that the formative assessment techniques used by English teachers in online learning were seen from their lesson plans. The formative techniques can be divided into three categories; those applied by all teachers, those applied by some teachers, and distinct techniques applied by only one teacher. The formative assessment techniques designed by teachers were summarized in Table 2.

Table 2 Formative assessment technique applied by the teachers

\begin{tabular}{ccc}
\hline $\begin{array}{c}\text { Formative } \\
\text { Techniques } \\
\text { applied by all } \\
\text { teachers }\end{array}$ & $\begin{array}{c}\text { Formative } \\
\text { Techniques } \\
\text { applied by } \\
\text { some teachers }\end{array}$ & $\begin{array}{c}\text { Formative } \\
\text { Techniques } \\
\text { applied by } \\
\text { only one of the } \\
\text { teachers }\end{array}$ \\
\hline $\begin{array}{c}\text { Questioning } \\
\text { Formative task }\end{array}$ & $\begin{array}{c}\text { Online } \\
\text { discussion }\end{array}$ & Self-assessment \\
Daily & & \\
Assessment & & \\
\hline
\end{tabular}


Based on table 2 showed that there were five formative assessment techniques that the teacher has prepared in carrying out online learning, namely questioning, formative task, daily assessment, online discussion, and selfassessment.

Based on the interview data showed that the teacher could not fully monitor whether students do the assignments honestly and independently, especially in asynchronous learning. The teacher explained that there were several types of dishonesty during online learning such as some students using technology to find ways to copy answers from other students or any sites and sometimes students manipulate technology to avoid teacher supervision.

Interestingly, this study found that one way for teachers to identify students' dishonesty is to check the stability of students' results from three formative assessment techniques, namely questioning, tasks, and test. First, the teacher gave assignments or tests to students in asynchronous meetings through Google Classroom or WhatsApp group. Then the teacher checked the students' assignments and if the teacher saw some of the same students' work, in the next meeting, the teacher conducted questioning activities about the topic from the assignment or test given to some of these students. So later, the teacher found which students cheated in doing the task and assessments given. There are several tools or platforms used by English teachers to conduct formative questioning, task, and daily test in online learning, such as Zoom, Google meet, WhatsApp, Buleleng Education Expose, Google Classroom.

Another technique is online discussion, this technique was only prepared by a few teachers in the lesson plan. Online discussions can provide a lot of information about students' mastery of the concepts being learned. The teacher used the tools or platforms to conduct discussion such as Zoom, Google meet, and WhatsApp group. The last technique is selfassessment. T1 was one of teachers who used the self-assessment technique in online learning. T1 believed that this technique was very useful when learning online to find out the weaknesses and strengths of students. However, only one out of five teachers prepare this technique, therefore it is hoped that in the future all teachers will also implement this aspect considering the many benefits that can be obtained from selfassessment.

\section{DISCUSSION}

This section discusses the research findings by interpreting, comparing, and evaluating according to the theoretical framework applied in this study. The findings have provided that several examples of how formative assessment can be planned in the lesson plan.

First, based on the document's data there are some points related to how the teacher shared learning goal from the material to be taught, namely by providing examples of the material and providing questions that help students understand what they should know and why they should learn. These results are in accordance with previous studies from Alock and Inglis (2018) also explain that examples have an essential role in developing conceptual understanding and can facilitate students in understanding the theory. Besides giving examples, the teacher also planned to conduct questioning in order to provide students with an understanding of learning goal. This finding supports the idea that questioning is one technique used to collect evidence of student progress (Wylie, C \& Lyon,2016; Jiang,2014). It also explains that the teacher should be good at asking questions to students because the teacher with weak questioning strategies will lose opportunities to know students' understanding.

Second, the success criteria dimensions. The data from the interview showed that all the English teachers agreed that success criteria play a significant role in learning. The data from documents also showed that the learning goal and the success criteria were in accordance with basic competencies (KD) and Indicators of competency achievement. However, some teachers need more detail in designing this dimension in order to maximize the potential 
164 JINOTEP (Jurnal Inovasi dan Teknologi Pembelajaran) Kajian dan Riset dalam Teknologi Pembelajaran Vol.8, No.2, Juli 2021, Hal. 157-166

benefit of formative assessment. As stated by Wylie and Lyon (2016), which mentioned that it is vital for a teacher to communicate success criteria clearly to students to help them understand how to achieve learning objectives.

The last, the dimension of learning progression. Based on table 2 showed that there were five formative assessment techniques that the teacher has prepared in carrying out online learning, namely questioning, formative task, daily assessment, online discussion, and selfassessment. These formative assessment techniques prepared by the English teacher to gather students information and make instructional decisions to improve learning were in line with the previous research (Ogange et al.,2018; Kenyon,2019; Jiang,2014; Chapuis,2015; Kang et al.,2014).

The first technique that appeared in the teacher's lesson plan is questioning. is defined as the activity of asking questions to check students' understanding as seen from their answers(Jiang, 2014). As stated by Defianty (2018), questioning is one of the formative assessments that has high flexibility to be applied at every stage of learning. The teachers can use questioning to check for student understanding. Questioning should be implemented appropriately to be beneficial to the formative assessment process because students' answers can provide information about the progress of their competency mastery. The documents data showed that the English teachers used several tools or platforms to conduct formative questioning such as Zoom and Google meet.

Formative task is the task given by the teacher that is used to identify student understanding and will later be given feedback to improve student progress (Chan et al., 2014). Based on the interview, the English teacher gave varied types of formative tasks such as true and false questions, multiple-choice, matching tasks, gap filling, etc. The teacher also explained that they provided assignments in the form of worksheets, PowerPoints, and videos. It is in line with Moh Arief (2016) explains that giving individual assignments is one way to get students' information related to the level of English mastery and identify problems faced by students in learning. This study found that the teacher provided varied and different tasks every week with the aim that students were always enthusiastic during online learning. this study, the example of tools or platforms that used by the teacher to transfer formative tasks, that is Google Classroom and WhatsApp.

Discussions build knowledge and develop critical and creative thinking skills. Based on Conderman \& Hedin (2012) suggests that class discussion as one effective formative assessment strategies to determine what students already know about the material. In addition, Arise (2018) explains that the use of discussion improves the ability of students in reading comprehension. The documents revealed that the example of tools or platforms used by teachers to conduct online discussion, that were; Zoom, Google meet, and WhatsApp group.

The next technique is daily test. It is one of the most commonly used formative techniques. The daily test is usually held at the end of the chapter of a lesson. The daily test aims to determine the extent of students' understanding of the material given. Teachers used daily tests to categorize students for further instruction, to identify learning difficulties, and to follow up specific students with remedial teaching and/or remedial tests. In line with Carless (2012) states teachers can use the test's results to adjust instruction in learning to maximize the potential test to enhance learning.

The last technique is self-assessment, the teacher believed that this technique is very useful when learning online to find out the weaknesses and strengths of students. In addition, using selfassessment gives students the opportunity to assess themselves freely. Lesmana \& Rokhyati (2020), self-assessment makes students aware of the lesson being taught and it helps students to develop strategies for learning. However, only one out of five teachers prepare this technique, therefore it is hoped that in the future all teachers will also implement this aspect considering the many benefits that can be obtained from self- 
assessment. As stated Mohamed Jamrus \& Razali (2019), self-assessment can help teachers manage their assessments better without any students left behind.

As a result, the study found that all English teachers had made a plan before carrying out online learning. It indicated the English teachers had implemented the Regulation of the Minister of National Education Regulation Number 41 of 2007, which states that every teacher in an education unit is obliged to compile a complete and systematic lesson plan. It is intended that learning can take place in an interactive, inspirational, fun way, motivates students to participate actively, and provides sufficient space for initiative, creativity, and independence according to the talents, interests, and development of students. Even though several teachers need to be more detailed in planning the formative assessment on their lesson plan, especially in preparing how to communicate the dimensions of success criteria, the teachers in this study successfully integrated formative assessment planning into their onepage lesson plan. This results in line with Kemendikbud Republik Indonesia (2020) states that in order to make the formative assessment and learning to become a unit, formative assessment planning should be integrated with the lesson plan.

\section{CONCLUSION}

This study aims to examine the formative assessment planning in online learning. Based on the results of the finding and discussion of this study, there were several points can be concluded. First, the English teachers at SMP N 1 Singaraja successfully integrated formative assessment planning into their one-page lesson plan. Second, the teacher prepared the authentic example and questioning activity as a way to help students understand the learning goals. Third, there were formative techniques prepared in synchronous learning such as questioning, daily test, and online discussion through Zoom/Google meet, Google Classroom, and WhatsApp. In comparison, the techniques applied by teachers in asynchronous meetings such as formative tasks and selfassessments. However, the dimensions of success criteria still need to be considered and improved in order to maximize the benefit of formative assessment in online learning.

The results of this study could have positive implications for future practice. The intention of this study is to analyze how the teachers design the formative assessment planning for English subject in online learning. Thus, the results of this study can be adopted by other teachers as the reference in preparing formative assessment in online learning. With the results of this study, the teachers may be better able to concern and improve the use of formative assessment that helps them to monitor students' difficulties and adjust their instruction in online learning.

\section{REFERENCES}

Arise, N. (2018). The Effectiveness of Small Group Discussion Method in The Teaching of Reading Comprehension. 20400113002.

Atmowardoyo, H. (2018). Research Methods in TEFL Studies: Descriptive Research, Case Study, Error Analysis, and R\&D. Journal of Language Teaching and Research. 9(1). 197204.DOI: http://dx.doi.org/10.17507/jltr.0901.25

Carless, D. (2012). From Testing to Productive Student Learning: Implementing Formative Assessment in Confucian-heritage Settings. New York: Taylor \& Francis. Retrieved from https://books.google.com.au/books?id=7trFBQ AAQBAJ

Creswell, J. W. (2012). Educational research (4th ed.). Boston, MA: Pearson Education, Inc

Chappuis, J. (2015). Seven strategies of assessment for learning (2nd ed). Upper Saddle River, N.J: Pearson Education.Black, P., \& Wiliam, D. (1998). Assessment and classroom learning. In International Journal of Phytoremediation (Vol. 21, Issue 1). https://doi.org/10.1080/0969595980050102

Defianty, M. (2018). The practice of formative assessment by EFL teachers in secondary high school in Indonesia.

Heale, R., \& Forbes, D. (2013). Understanding triangulation in research. Evidence-Based Nursing, 16(4), 98. https://doi.org/10.1136/eb2013-101494

Andrade, H. L., \& Heritage, M. (2017). Using Formative Assessment to Enhance Learning, Achievement, and Academic Self-Regulation. In Using Formative Assessment to Enhance Learning, Achievement, and Academic SelfRegulation. https://doi.org/10.4324/9781315623856 
166 JINOTEP (Jurnal Inovasi dan Teknologi Pembelajaran) Kajian dan Riset dalam Teknologi Pembelajaran Vol.8, No.2, Juli 2021, Hal. 157-166

Kang, H., Thompson, J., \& Windschitl, M. (2014). Creating opportunities for students to show what they know: The role of scaffolding in assessment tasks. 98(4), 674-704. doi:10.1002/sce. 21123

Kemendikbud Republik Indonesia. (2020). Model penilaian formatif. 64 .

Kenyon, B. J. (2019). Teachers ' Formative Assessment Use to Check for Understanding and to Adjust Instruction. Walden Dissertation and Doctoral Studies, February.

Lesmana, N., \& Rokhyati, U. (2020). The Implementation of Doing Self-Assessment in Higher Education. Journal of English Language Studies, 5(1), 60-72. http://jurnal.untirta.ac.id/index.php/JELS

Leibold, N., \& Schwarz, L. M. (2015). The art of giving online feedback. Journal of Effective Teaching, 15(1), 34-46. http://ezproxy.ace.edu/login?url=http://search. ebscohost.com/login.aspx?direct=true \&AuthT ype $=\mathrm{ip}$, uid $\& \mathrm{db}=$ eric $\& A N=\mathrm{EJ} 1060438 \&$ site $=e$ ds-live \&scope $=$ site

McCarthy, J. (2017). So all can learn: A practical guide to differentiation. Lanham, MD: Rowman \& Littlefield.

McLaughlin, T., \& Yan, Z. (2017). Diverse delivery methods and strong psychological benefits: A review of online formative assessment. Journal of Computer Assisted Learning, 33, 562-574. ://dx.doi.org/10.1111/jcal.12200

Mohamed Jamrus, M. H., \& Razali, A. B. (2019). Using Self-Assessment as a Tool for English Language Learning. English Language Teaching, 12(11), 64. https://doi.org/10.5539/elt.v12n11p64

Muhsin, Muh Arief. (2016). Teknik Penilaian Dalam Pembelajaran Bahasa. Retrieved from https://adoc.pub
Nishanthi, R. (2018). The Importance of Learning English in Today World. International Journal of Trend in Scientific Research and Development, Volume-3(Issue-1), 871-874. https://doi.org/10.31142/ijtsrd19061

Ogange, B. O., Agak, J., Okelo, K. O., \& Kiprotich, P. (2018). Student Perceptions of the Effectiveness of Formative Assessment in an Online Learning Environment. Open Praxis, 10(1), https://doi.org/10.5944/openpraxis.10.1.705

Perera-Diltz, D. M., \& Moe, J. (2012). Online instruction of counselor education coursework: Maximizing strengths and minimizing limitations. Ideas and Research You Can Use: VISTAS.

Pusat Asesmen dan Pembelajaran Kementerian Pendidikan dan Kebudayaan. (2020). Buku Saku Asesmen Diagnosis Kognitif Berkala.

Jiang, Y. (2014). Exploring teacher questioning as a formative assessment strategy. RELC Journal, 45(3), 287-304. doi: $10.1177 / 0033688214546962$

Sugiyono. (2018). Metode Penelitian Kombinasi (Mixed Methods). Bandung: CVAlfabeta.

Wiliam, D. (2013). Assessment: The bridge between teaching and learning. Voices from the Middle, 21(2), 15-20. Retrieved from https://www.ncte.org

Wylie, C., Lyon, C., \& Formative Assessment for Students and Teachers (FAST) State Collaborative on Assessment and Student Standards. (SCASS). (2016). Using the formative assessment rubrics, reflection and observation tools to support professional reflection on practice. Washington, DC: Council of Chief State School Officers. 